\title{
Assessment of climate indices and NDWI analysis in Lerma Chapala basin
}

\author{
Miriam Castro-Lazcarro 1, Valentina Davydova-Belitskaya ${ }^{2}$, and Abraham Cárdenas-Tristán 1,*
}

1 Center for Research and Postgraduates Studies, Engineering Faculty, University of San Luis Potosí, Av. Dr. Manuel Nava No. 8, San Luis Potosí, SLP - Mexico. C. P. 78210.; miriamcastro1091@gmail.com

2 Department of Environmental Sciences, University of Guadalajara, Camino Ramón Padilla Sanchez 2100 Nextipac, 45200 Zapopan, Jal. - Mexico C.P. 45200; valentina.davydova@academicos.udg.mx

1 Center for Research and Postgraduates Studies, Engineering Faculty, University of San Luis Potosí, Av. Dr. Manuel Nava No. 8, San Luis Potosí, SLP - Mexico. C. P. 78210.; abraham.cardenas@uaslp.mx

* Correspondence: abraham.cardenas@uaslp.mx

\begin{abstract}
Lake Chapala is a natural ecosystem of Mexico, declared Ramsar site, currently, is an area with importance in the agricultural sector, tourism, and important source of drinking water in the Metropolitan area of Guadalajara, considered as a thermo regulatory body. This study used tools such as Rhtest, as well as analyzing extreme climate indices using RClimdex. In addition, the relationship with the change in water surface of Lake Chapala was assessed through the NDWI index, using Landsat images, between 1985 and 2018. According to the obtained results, the signs of climatic variability are detected in the study region, which, directly affects the basin runoff and water levels in the lake, as well as, the factor of water overexploitation in the basin, so it is considered that the lake conditions mostly depend on the type of management that is given to the resource. Finally, the results will help the understanding of climate variability and its water resources influence of the Lerma Chapala basin, which will assist in future research.
\end{abstract}

Keywords: Chapala Lake; Climate change; RClimdex; NDWI; Water management

\section{Introduction}

The hydrosphere is the element strongly linked to the quality of population life, which covers about $71 \%$ of the Earth, however, in recent years the reduction of usable water on the planet has been demonstrated, as a result of climate change, as well as, an increase in the exploitation of the resource, both factors have conditioned significant droughts in different world regions. We can give many references of this, for example, the physical modification that Lake Chad has undergone in Africa has caused global alarm, due to the reduction of its surface area, despite having been worldwide one of the lakes with the greatest coverage. It should be noted that the behavior patterns of some variables influence others, i.e. water management depends directly on the interaction between human activities and ecosystems, with better water resource management, which leads to greater awareness in the decision-making of key actors in each region [1].

According to the Intergovernmental Panel on Climate Change (IPCC) [2], lakes and rivers have the most important changes related to climate variability. Different projections show that climate change will decrease surface and groundwater, mostly in subtropical ecosystems, creating greater competition between water regions.

The water available for human consumption comes from an imbalance between continents and oceans, i.e. water that is precipitated and water that evaporates regions; However, in the oceans there is a reverse phenomenon, because evaporation is approximately $10 \%$ higher than precipitation, and therefore potential water resources of use depend directly on surpluses between continents and oceans [3]. The decline or disappearance of 
water bodies is the greatest consequence of climate change, coupled with overexploitation of their source, endangering communities, because it is the cause of decreased water availability for human consumption, in the same way, it is determined for the industrial sector, where many of the processes depend on the water resource [4].

In the last two decades, the analysis and measurement of the Earth's surface has involved various hydrological and meteorological parameters, which are necessary for geospatial modeling techniques for vegetation analysis, water supply in a basin, precipitation models, temperatures, radiation, among others. Currently, the generation of highresolution climate maps, it is necessary for a local, regional, national and international diagnosis; it should be noted that for the generation of information through spatial analysis it is necessary to use different databases from official sources, however, the use of remote sensing for climate analysis involves the management of data by means of satellite radars, which generate limited data because the images do not always have good quality for their analysis [5].

The climatic information includes various areas of study such as: soil science, topography, vegetation type, underground geomorphology, hydrology, pollutants, among others; which have the function of multidisciplinary integration of the various studies, as well as, corroborate through geostatistical processes, which in turn are represented by thematic maps at the national, regional and local levels, i.e. the information can be interpreted according to the source, with the aim of integrating the complex process, adding the climate and meteorological databases. In other words, the analysis of complex projections can be represented with digital maps without the loss of process information [6].

Currently, the use of new technologies for climate change analysis is more important due to reliability of results compared to other methods, i.e. the use of technology contributes to the creation of reliable mitigation strategies; a widely used tool internationally has been RClimdex, which analyzes historical databases and representing them graphically; their beginnings took place in South Africa in 2004, however, it is important to note the use of the homogenization process in databases through Rhtest due to the need for reliable information from climatic variables [7].

This study analyses changes in the water surface of Lake Chapala using Landsat satellite (3 MSS, 5 TM, 7 MES and OLI 8) from 1985 to 2018, as well as the relationship with climatic variables; temperature (maximum and minimum) and precipitation, of the Lerma Chapala basin.

Research through remote sensing is widely used in different areas, such as water body analysis, coastal zone management, erosion monitoring (water, wind, gravitational, relief or desertification), natural disasters, among others; However, the information posed by monitoring bodies of water by means of Landsat images is sufficient compared to other topics of interest [8]. The use of the Standardized Water Index (NDWI) for water body analysis is carried out through multispectral sensors, which maximize the utilization for spatial analysis of surface water bodies, and therefore direct efforts for the correct use of information and the generation of timely actions for mitigation [9].

Lake Chapala is considered to be an ecosystem with high value in the central region of Mexico, due to its dimensions, it is the largest lake in Mexico and the third largest in Latin America, that is, it provides different environmental services to the region, it is a thermo regulatory body in the Lerma Chapala Santiago basin, since it has an area of approximately $130,000 \mathrm{~km} 2$, making it the body of water on which the region directly depends, that is, the municipalities around it depend on the activities related to the lake [10]. The study area is located at coordinates $20^{\circ} 15^{\prime} 14^{\prime \prime}$ to $20^{\circ} 17^{\prime} 26^{\prime \prime}$ North and $102^{\circ} 40^{\prime} 45^{\prime \prime}$ to $103^{\circ} 25^{\prime} 30^{\prime \prime}$ West, with an altitude of 1,510 meters above sea level, the region covers the territories of Jalisco (86\%) and Michoacán (14\%), also has a capacity of up to 8, $000 \mathrm{~km} 3$ the depth depends on the point to be measured, however, on average it has $7.7 \mathrm{~m}$; however, there are records of areas ranging from 4 to $11 \mathrm{~m}$. In 2008, it was declared a Ramsar site, due to the migration of birds of international importance, as well as, place of refuge, food, hibernation and reproduction of species [11]. Nevertheless, there has been a decrease in the area, as some of the problems surrounding the lake are water demand and 
climate variability, i.e. despite intra annual and year over year, one was found to have declined; Otherwise, climatic conditions play a key role in the state of the lake, as well as, of conditions outside the region, it should be noted that the decrease or increase of water surface area is a key process to understand the ecosystem dynamics [12]. However, it is important to understand the regional economy, where the development of urban and industrial economic policy prevails and as a consequence the lake resource has been oriented to meet the demand of cities; in the last 50 years the central region has been considered as a strategic area due to climatic conditions, though, it has caused a rapid degradation of ecosystems and in turn has changed the amount of water that reaches the lake [13]. Currently, the municipalities that make up the Chapala basin have defined the main economic activities, mainly tourism, livestock and agriculture, nevertheless, the amount of water demand generated by the activities is considered to be lower than that demanded by the Metropolitan Zone of Guadalajara (ZMG), up to $60 \%$, the ZMG is located approximately $30 \mathrm{~km}$ from the lake [14], see figure 1.

Figure 1. Location of the Lerma Chapala basin.

It is important to mention that the basin of Lake Chapala has an exorheic system, its main water supplier is the Lerma River, which originates from the State of Mexico, in turn, the Santiago River originates in the lake and flows into the Pacific Ocean [15]. It has a variety of soils type, but mainly corresponds to the type of Phaeozems associated to mountain zones

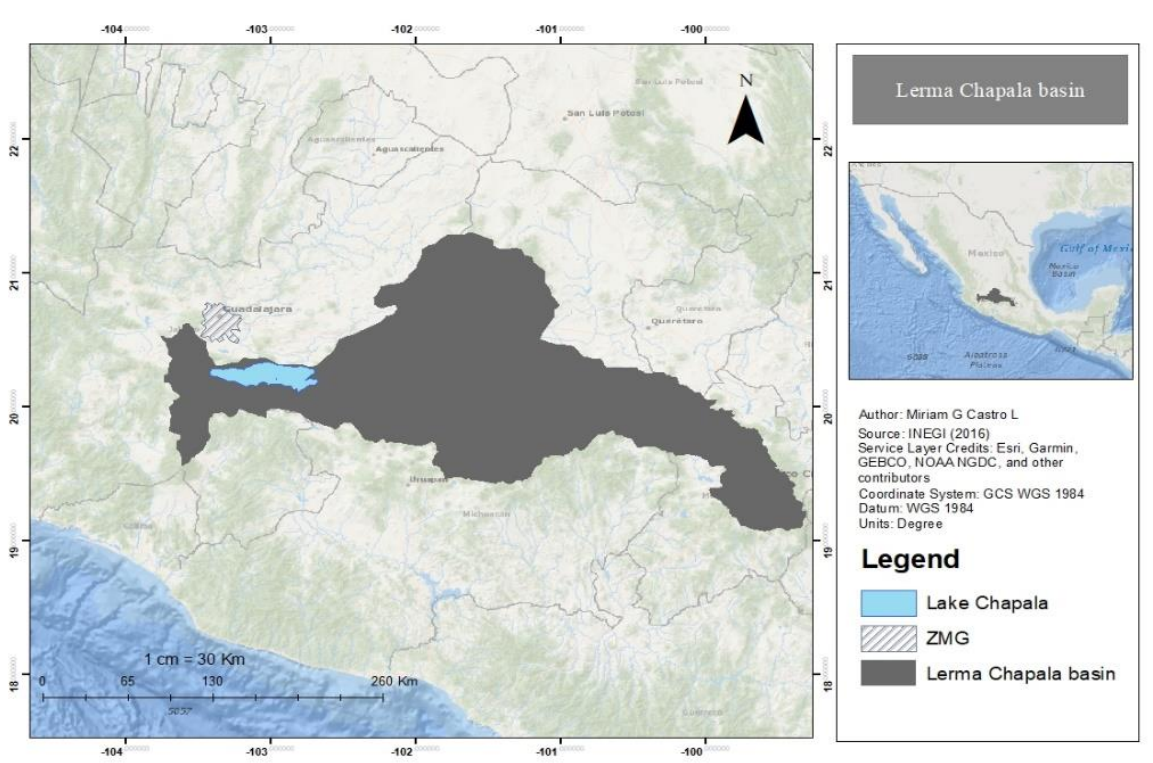

and low

hills and

Vertisols related to Chapala flatland and Bajio area [16].

It should be noted that historically there are records of low rainfall, since in the 1940s and for 13 years 
a dry environment prevailed in the region, however, it is considered that the Metropolitan Zone of Guadalajara is the most important city in the area and had a constant population and industrial growth, which led to an water overscath and by default it was found that the best way to alleviate demand was by extracting the resource from the lake; It was also in 1950 that the Lerma Chapala basin focused its development on the industry, causing an increase in cities, giving way to one of the most important regions of the country, with basic resources that ensured growth and where water played a very important role, however, this development caused problems with supply, committing the prosperity of the region, since the basin exploration wells began; This demand for the water resource at the top of the basin violated water availability in the lower area. Though, in 1980 it began with the construction of an aqueduct that would directly bring water to the city of Guadalajara from the lake, which would cause greater scarcity in Lake Chapala. According to the records, in 2001 one of the worst droughts was suffered, and as a result, Lake Chapala ceased to be central axis in the development plans of the Lerma Chapala basin [12]. In addition, a significant part of the problem of the lake supply are the number of hydraulic infrastructure situated in the basin, give that within the region Lerma Chapala are 517 dams, the states with the greatest infrastructure are; Michoacán (189), Guanajuato (177), State of Mexico (91), Jalisco (41) and Querétaro (5), as can be seen in Figure 2 [17].
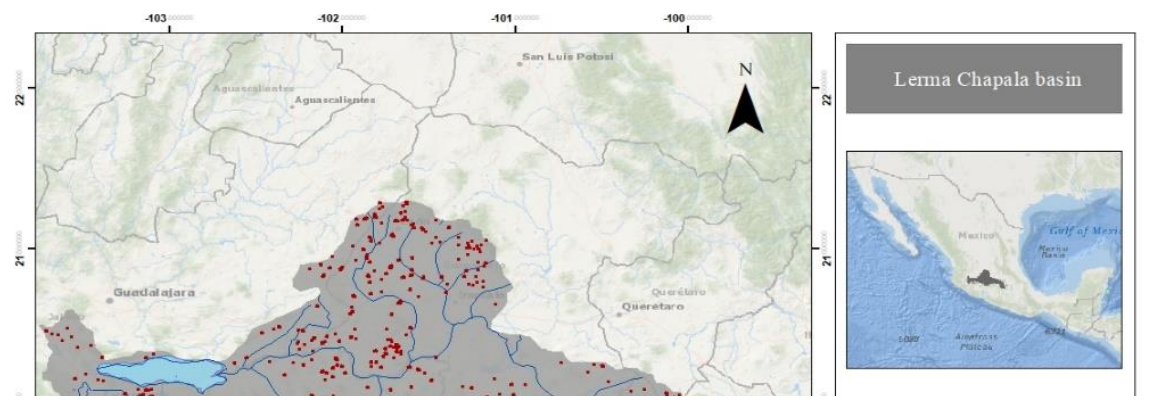

Figure 2. Distribution of water infrastructure through the Lerma Chapala basin.

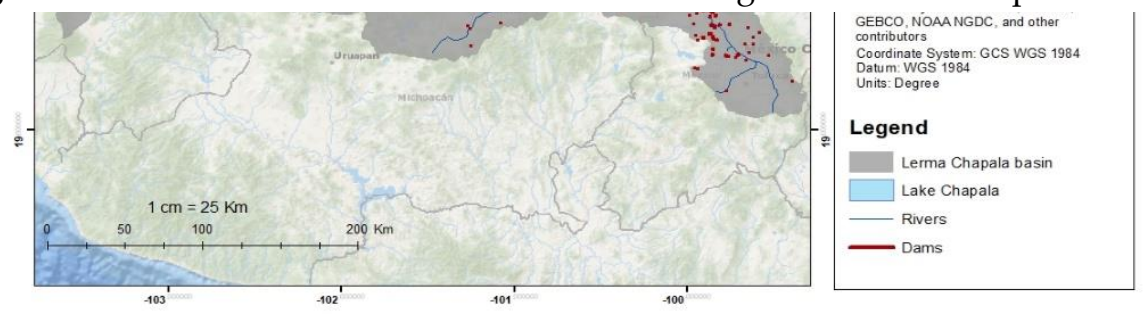

2. Mate-

rials and Methods

\subsection{Climate variables}

Initially the study site was described, where through the bibliographic review and the collection of meteorological data from the climatic stations of CONAGUA (2018) [18]; It was useful for the creation of a climatic profile of Lerma Chapala basin, where it could be observed that the catchment area has a well-defined wet season during the summer, with an average annual volume of $875 \mathrm{~mm}$ [19]. According to the analysis carried out of the temperature, different ranges were identified, which, are directly proportional to the altitude change of the basin and which, in turn, modifies the type of climate, therefore, the basin was subdivided into three areas: high, medium and low. It is important to note 
that SEMADET (2006) [4] previously performed a sub-water classification; it was identified that, in the upper region, corresponding to the State of Mexico and Querétaro, with an average annual rainfall of $723 \mathrm{~mm}$; the middle zone comprises the states of Michoacán and Guanajuato and has an average annual volume of 602 to $658 \mathrm{~mm}$; and the lower part located in the state of Jalisco has an average annual rainfall of 681 to $756 \mathrm{~mm}$ [19], as shown in Figure 3.

According to the Report of the Intergovernmental Panel on Climate Change (IPCC) (2018) [20] human incidence is directly proportional to the observed impact on ecosystems, where many of the changes since 1950 have been unprecedented in recent decades to millennia; and therefore the temperature variable is most susceptible to climate variability, due to its vulnerability. It should be noted, that the Lerma Chapala basin has different maximum temperature ranges, depending on the region, at the top it can be presented on average from 21 to $23^{\circ} \mathrm{C}$, however, in the middle region a warmer behavior is observed, with an average annual dating from 24.5 to $27.5^{\circ} \mathrm{C}$ and the lower part has higher temperature compared to the other two zones, with an average maximum temperature of 25 to $28^{\circ} \mathrm{C}$ [19]. See Figure 4 .

It is important to note, that according to IPCC (2014) [21] the prolonged changes that occur in the minimum temperature are indicators of climatic alterations, therefore, it is important to underline these trends that shows the climatic alteration in the region of the Lerma Chapala basin. According to the analysis carried out, it was identified that the areas of the study region have a well-differentiated behavior from them, i.e. the upper area has the lowest minimum temperatures ranging from 3 to $9.7^{\circ} \mathrm{C}$, in the middle region there is a wider range of temperature, where most of the territory impact temperatures ranging from 7.9 to $12.1^{\circ} \mathrm{C}$, however, the area surrounding Jalisco and near Lake Chapala has a higher range of the average minimum temperature ranging from 12.1 to $21.3^{\circ} \mathrm{C}$. Finally, the low region, corresponding to Jalisco, has the highest minimum temperature of the Lerma Chapala basin, which ranges from 7.9 to $21.3^{\circ} \mathrm{C}$, it is worth mentioning that the warmest area corresponds to Lake Chapala, as shown in Figure 5 [19].

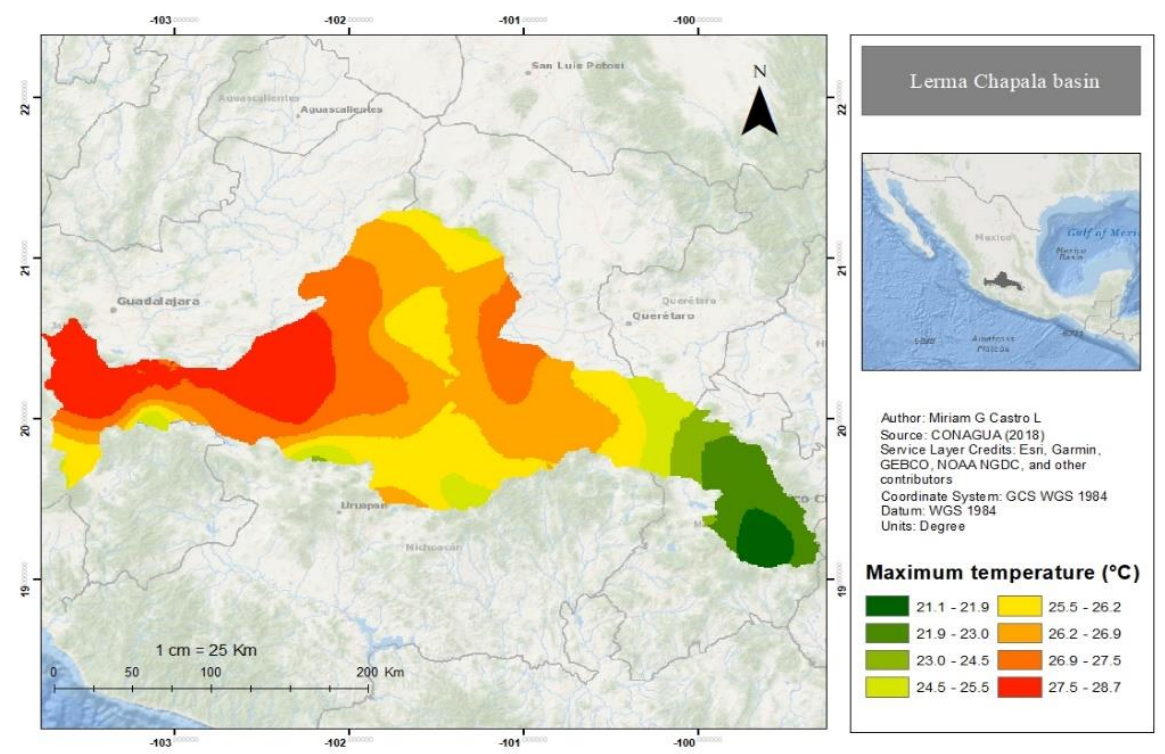




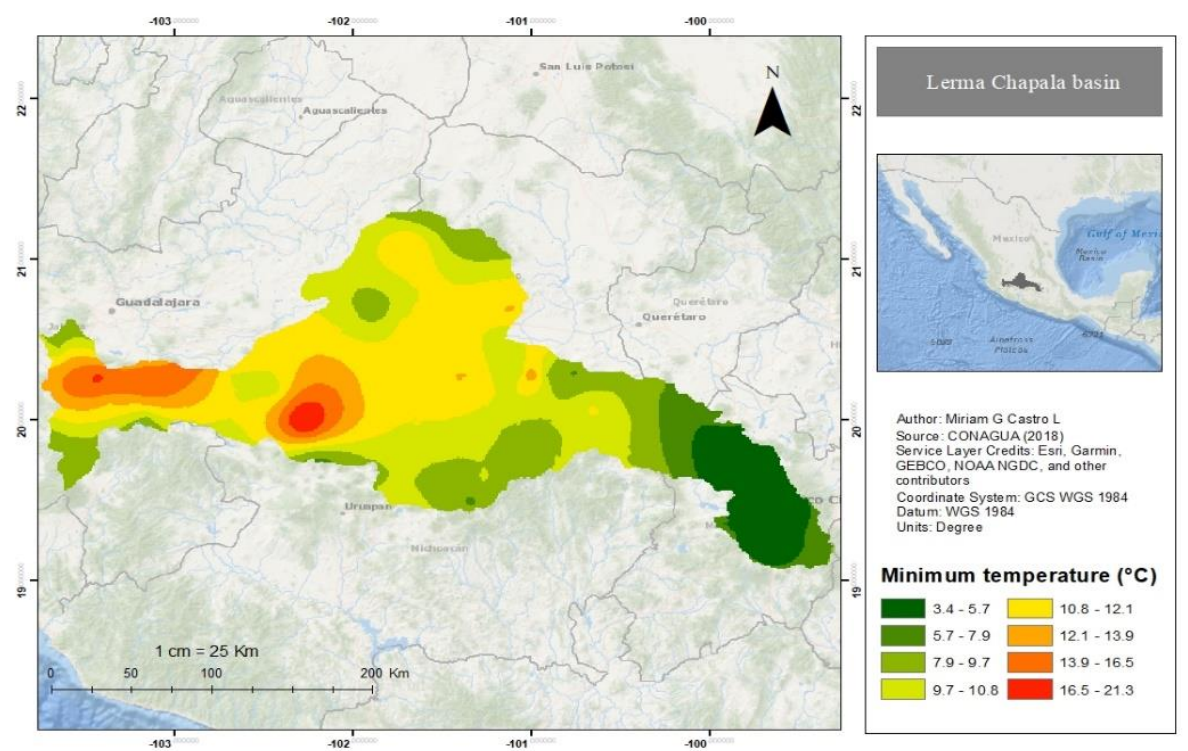

Figure 4. Average maximum temperature of the Lerma Chapala basin.
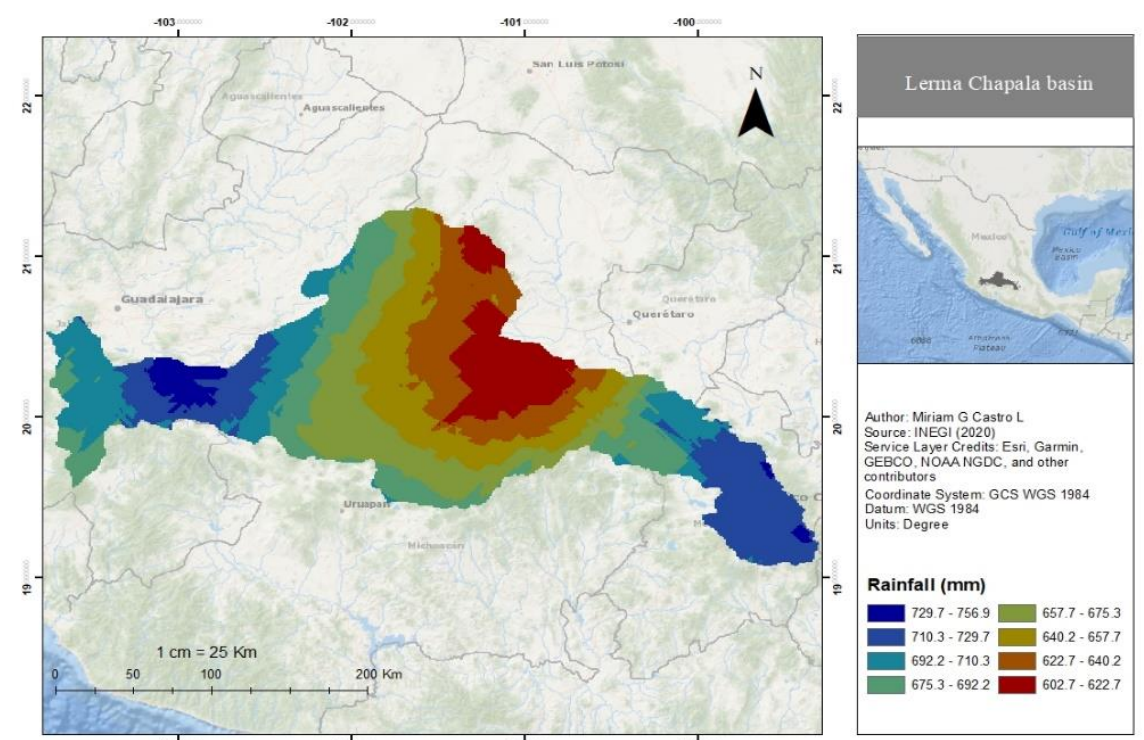

Figure 5. Average minimum temperature of the Lerma Chapala basin.

Initially, the databases of 60 weather stations were downloaded, through the National Weather Service [22], located in the Lerma Chapala basin, however, following the methodology recommended, by the IPCC [2], it was applied data quality control, which must include three important traits; 1 . Current operation, 2. Data density (missing data volume should not be greater than $25 \%$ ) and 3 . Data persistence (must not be more than three years away from consecutive records); Nevertheless, it was necessary to correct errors thereof, i.e. the missing data and dates were filled in, and in the valueless spaces was added (-99.99), in order to be able to perform the analysis later in RClimdex 3.5.1; Once the information was analyzed by the $\mathrm{R}$ code, the need to homogenize the data by means of Rhtest was identified, according to the methodology created by Zhang and Feng (2004) [7], the suspicious information was detected in the databases. Eitherway, the suspicious data was validated by comparing it to same parameter of the nearest station to verify whether that data corresponded to extraordinary weather conditions or errors. Finally, once the station information was homogenized, just 18 climatic stations were selected, due to the data quality i.e. only those collect the quality control necessary for climate analysis for be evaluated. 
2.2 Assessment of the surface of Lake surface Chapala over time using Landsat images

Initially satellite images of the Lerma Chapala basin were collected from 1985 to 2018, through the official portal of the United States Geological Survey (USGS) [23], due to the resolution and quality of Landsat images; the selected years had a time interval of 5 years, in turn, the two representative seasons; dry and rain season were taken into account; However, images of different months were taken due to cloudiness conditions, Table 1 shows the dates and type of image.

Table 1. Information about Landsat images used in the study.

\begin{tabular}{|c|c|c|c|c|c|}
\hline Date & Path and Row & $\begin{array}{c}\text { Landsat } \\
3 \mathrm{MSS}\end{array}$ & $\begin{array}{c}\text { Landsat } \\
5 \text { TM }\end{array}$ & $\begin{array}{c}\text { Landsat } \\
7 \text { ETM }\end{array}$ & $\begin{array}{c}\text { Landsat } \\
\text { OLI } 8\end{array}$ \\
\hline 1985-01-04 & 2946 & $X$ & & & \\
\hline 1984-11-04 & 2946 & $X$ & & & \\
\hline 1990-03-07 & 2946 & & $X$ & & \\
\hline 1989-10-22 & 2946 & & $X$ & & \\
\hline 1995-04-22 & 2946 & & $X$ & & \\
\hline 1995-10-31 & 2946 & & $X$ & & \\
\hline $2000-04-19$ & 2946 & & & $X$ & \\
\hline $2000-09-10$ & 2946 & & & $X$ & \\
\hline 2005-03-24 & 2946 & & & $X$ & \\
\hline 2005-11-03 & 2946 & & & $X$ & \\
\hline 2010-04-07 & 2946 & & & $X$ & \\
\hline $2010-10-10$ & 2946 & & & $X$ & \\
\hline 2015-03-12 & 2946 & & & & $X$ \\
\hline 2015-11-23 & 2946 & & & & $X$ \\
\hline 2018-04-05 & 2946 & & & & $X$ \\
\hline 2018-11-15 & 2946 & & & & $X$ \\
\hline
\end{tabular}

Images that had an error were corrected using the tools provided by the ENVI software, then the Normalized Water Index (NDWI) was valued using formula 1:

$$
N D W I=\frac{\text { Green }-N I R}{\text { Green }+N I R}
$$

Subsequently, a spatial analysis was carried out by means of an unsaw classification of K-media, consisting of the grouping method, and finally, it was complemented by the creation of thematic maps, in order to visually analyze the changes over time of Lake Chapala, as well as extract the information from the lake surface through ArcGis, and thus be able to create an array of multitemporal surface data from the waterbody.

Figure 6 shows the outline of the methodology used in both the analysis of climatic variables and the study of satellite images for the water bodies evaluation of the Lerma Chapala basin. 


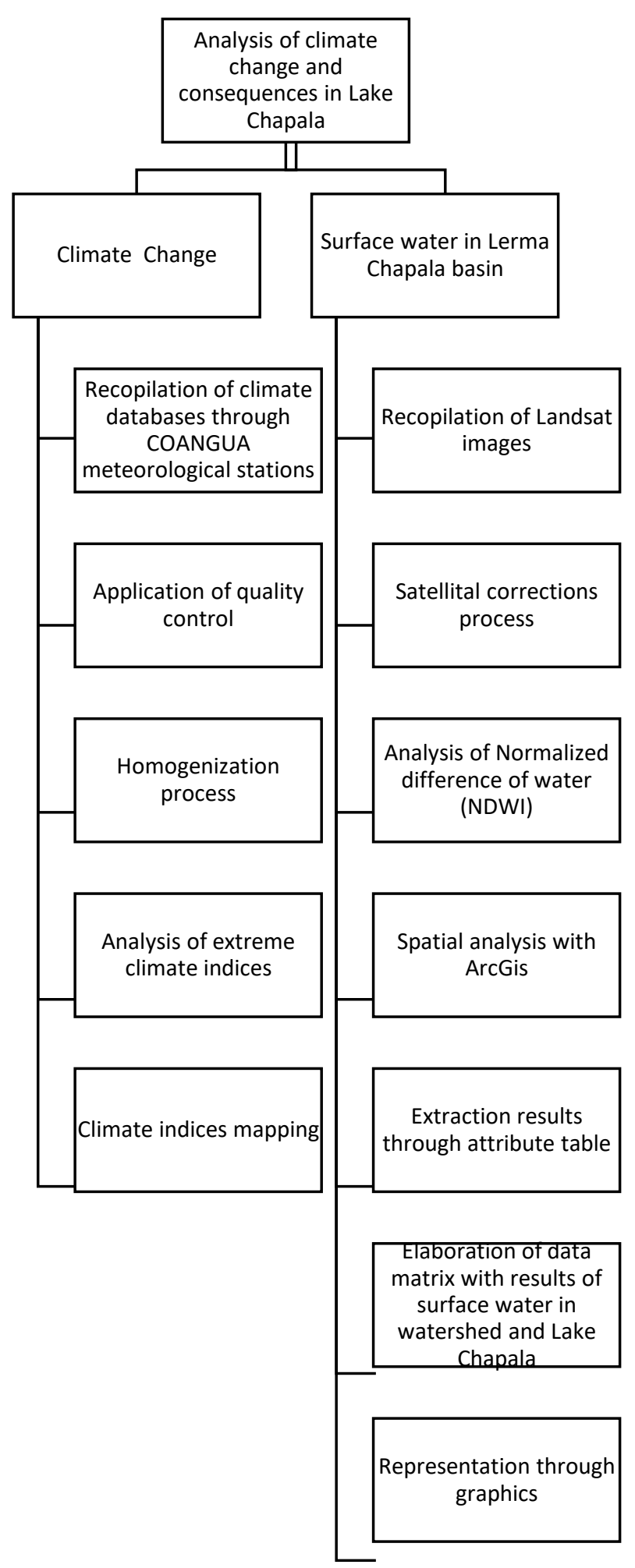

Figure 6. Methodology used in the present project.

\section{Results}

3.1 Climate variability

The results shown in figure 5 correspond to the analysis of climate indices, where an increase can be displayed in twelve of them; Average maximum temperature, summer days, maximum monthly value of maximum temperature, minimum monthly value of 
minimum temperature, daytime temperature range, maximum amount of rain per day and in five days, simple daily intensity index, regular rain, heavy and very intense rain, consecutive dry days, days with the highest humidity, extremely dry days and total precipitation. It is observed low behavior in minimum temperature indices, maximum value of minimum temperature, minimum value of maximum temperature, and consecutive wet days. It should be noted that of the 27 indices, recommended by the IPCC Expert Panel (2007) [2], 19 of those calculated at the 95\% confidence level were applied. However, the results of 6 indices considered most relevant to the analysis are shown for this article.

It is important to note that in the middle region of the basin it was not possible to use or manage reliable data from climatic stations, therefore the decision was made to remove them from the analysis, even if it determined a bias in the central region of the basin.

Figure 6 shows the behavior of consecutive wet days (CWDs), moisture reduction is displayed in the upper basin in 4 out of 7 seasons. In the middle area dominates mainly a decrease in the number of consecutive wet days. Finally, in the low region there is a homogeneous behavior of moisture reduction.

Figure 7 shows the temperature day range (DTR). The upper basin is recorded an increase in ranges; However, two stations show a reduction in the range. Similarly, in the middle basin there is a similar behavior, where, 6 of the 10 stations analyzed, have an increase in the temperature conditions, and only 4 of them have a reduction in the ranges. Though, when evaluating the index in the low basin, undifferentiated behavior is seen, because 4 out of 8 stations has an increase between temperature values, and vice versa.

Figure 8 shows the number of days with regular precipitation $(\mathrm{R} 10 \mathrm{~mm})$, in the upper basin an increase is identified in 4 out of 7 points and in the other 3 there is a reduction in the index. However, in the mid-basin it shows a decrease in the indicator by 7 of the 10weather stations, only 3 have an increase of the same. Finally, when evaluating R10mm in the low basin a descent was identified, showing itself in most stations except for a single point, where there is a positive trend behavior.

Figure 9 shows the index of the number of days with heavy rain (R25mm), in the upper basin has a homogeneous behavior, where there is an increase in all the seasons analyzed. However, in the middle basin there is heterogeneity, i.e. in 3 out of 10 climatic stations analyzed there is a reduction of $\mathrm{R} 25 \mathrm{~mm}$, though, at $7-10$ points have an intense precipitation increase. Similarly, in the lower basin presents a mixed panorama, however, it has a dominance of ascent in $\mathrm{R} 25 \mathrm{~mm}$, since only 3 out of 8 has a decrease in the index.

According to figure 10 which visibilizes the average maximum temperature (TMAXmean), in such a way, it can be observed that in the upper basin there is a well-defined behavior, where there is an increase in the index in all the stations analyzed. Similarly, in the average basin there is a prevalence of temperature increase, at 9 out of 10 of the points, only 1 shows a reduction of TMAXmean. Nevertheless, assessing the low basin identifies a heterogeneous trend, where $5-8$ stations have an increase in temperature and 3 of them have a reduction of TMAXmean.

Figure 11 shows the average minimum temperature (TMINmean), in the upper basin there is a panorama where the reduction of the average prevails in 5 of 7 climatic stations and only in 3 of them have an increase of it. Similarly, in the average basin a temperature drop behavior is displayed at $8-10$ points and only in 2 show an increase. Though, in the lower basin it has a mixed panorama, where half the seasons have an increase in TMINmean, and vice versa. 


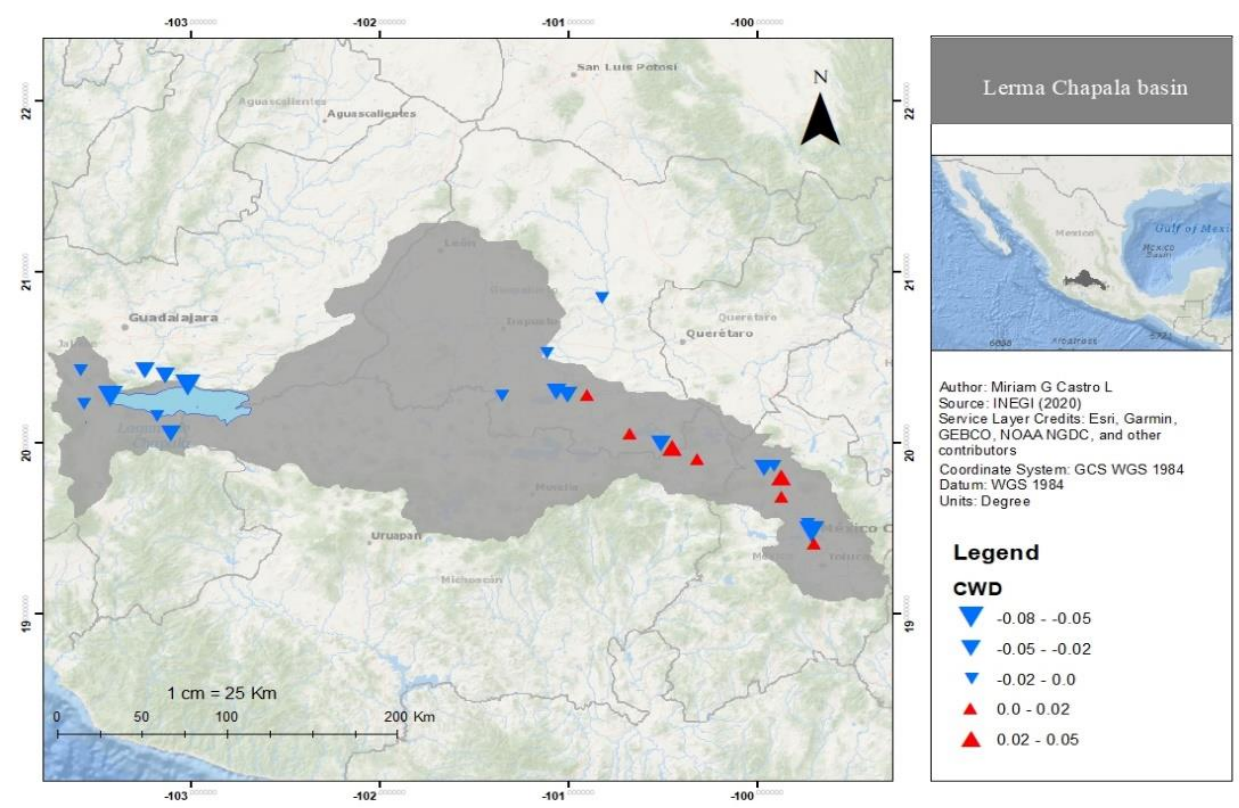

Figure 7. Indicator behavior of consecutive wet days (CWD) in the Lerma Chapala basin.

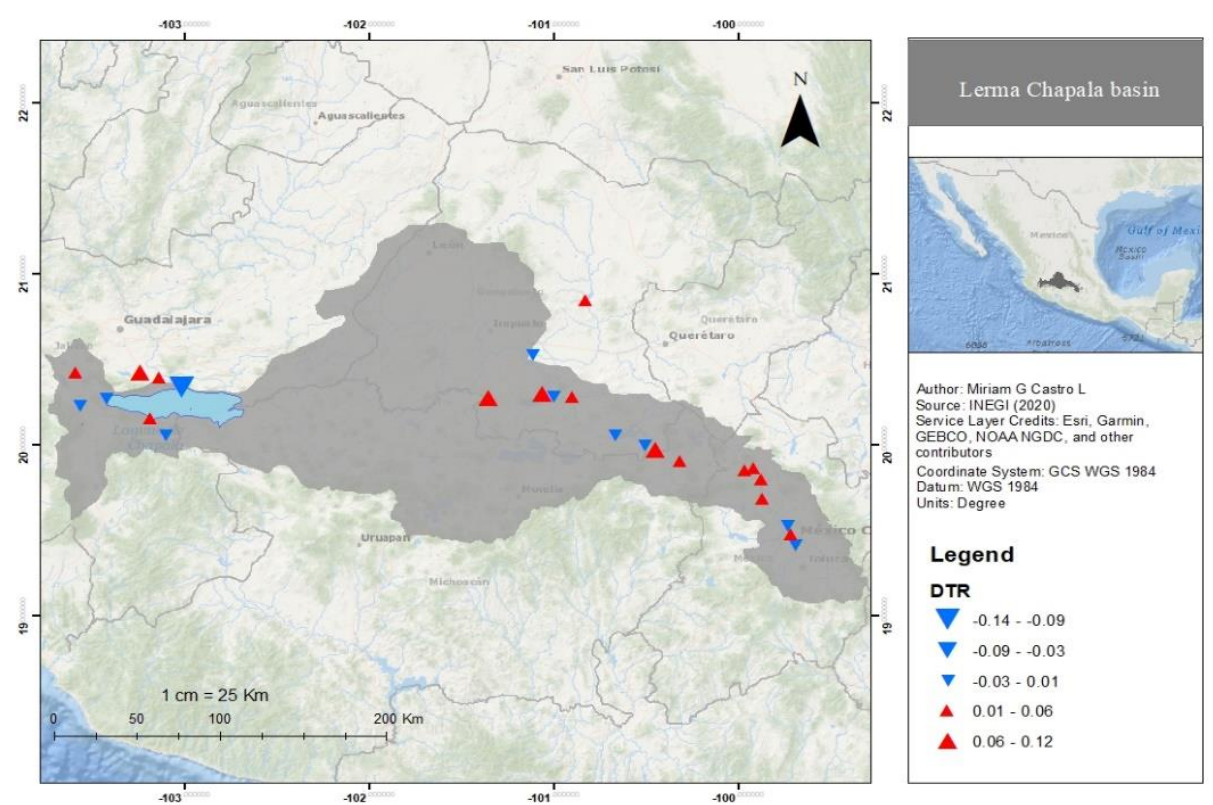

Figure 8. Analysis of temperature day ranges (DTR) in the Lerma Chapala basin. 


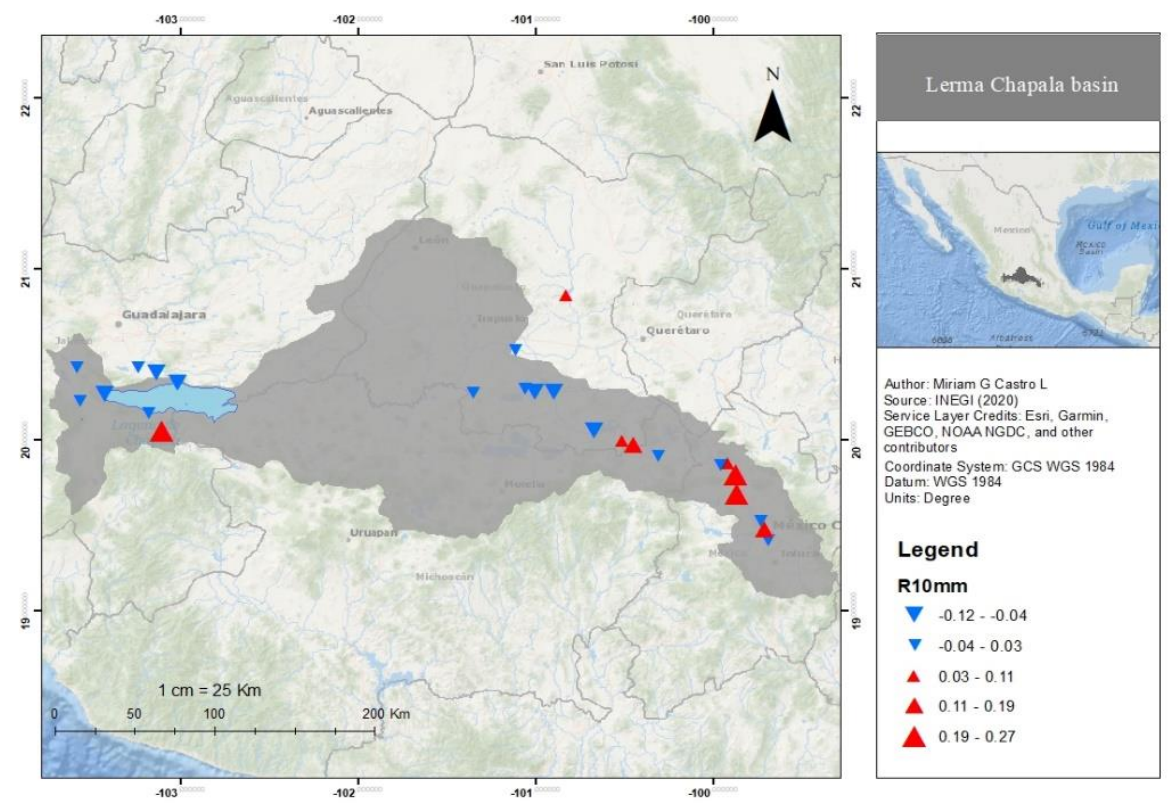

Figure 9. Analysis of extremely dry days (R99p) in the climatic seasons of the Lerma Chapala basin.

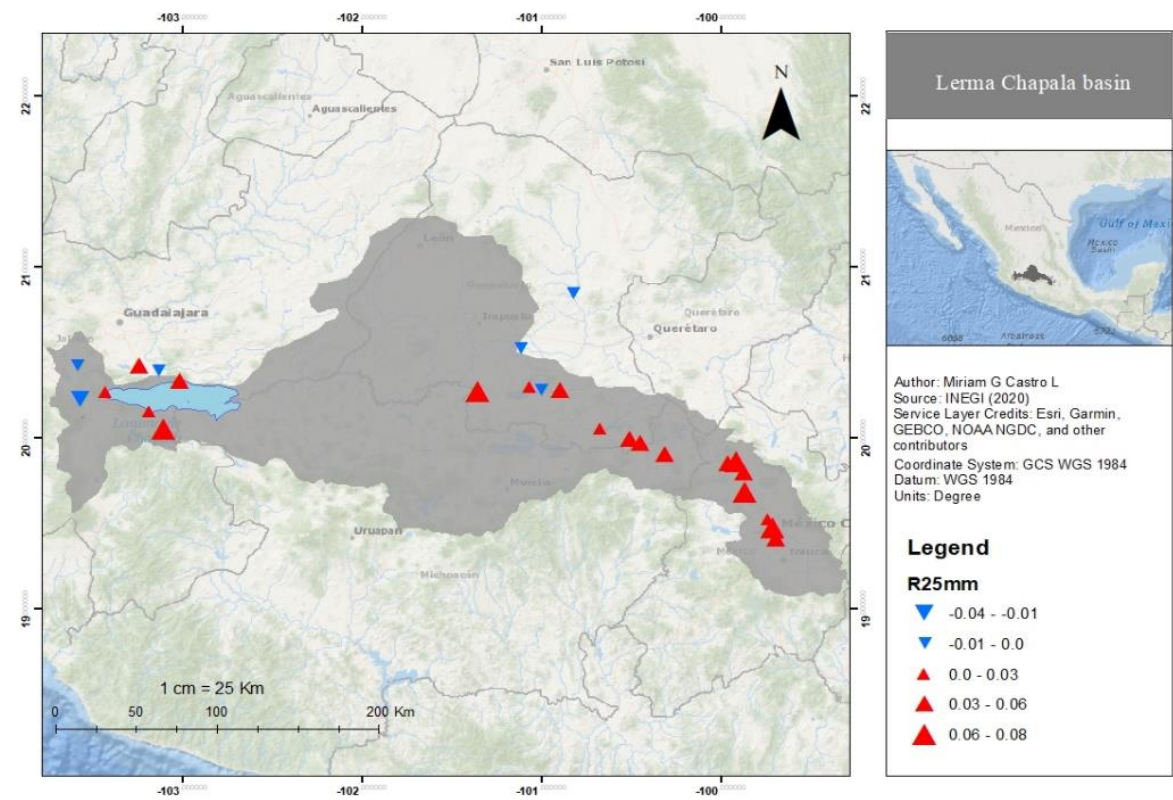

Figure 10. Behavior of the number of days with heavy rain $(\mathrm{R} 25 \mathrm{~mm})$ in the Lerma Chapala basin. 


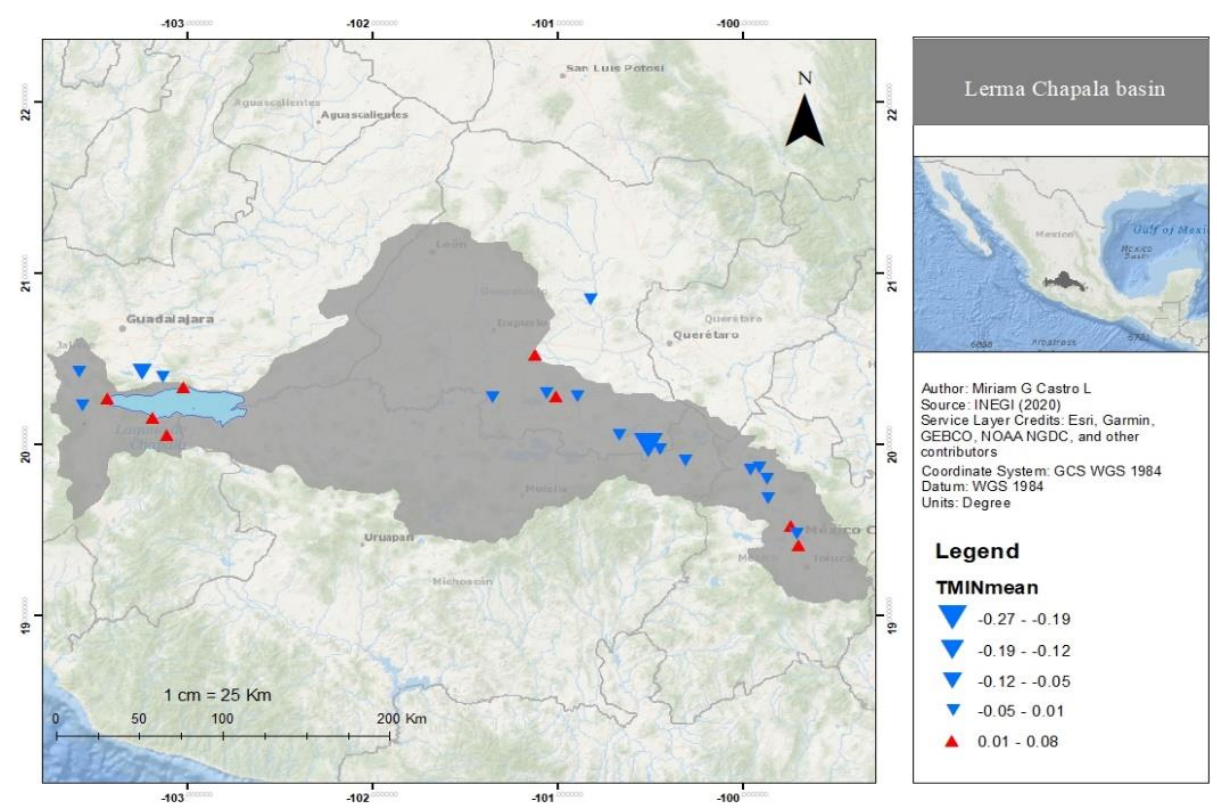

Figure 11. Analysis of the average maximum temperature (TMAXmean) in the Lerma Chapala basin.

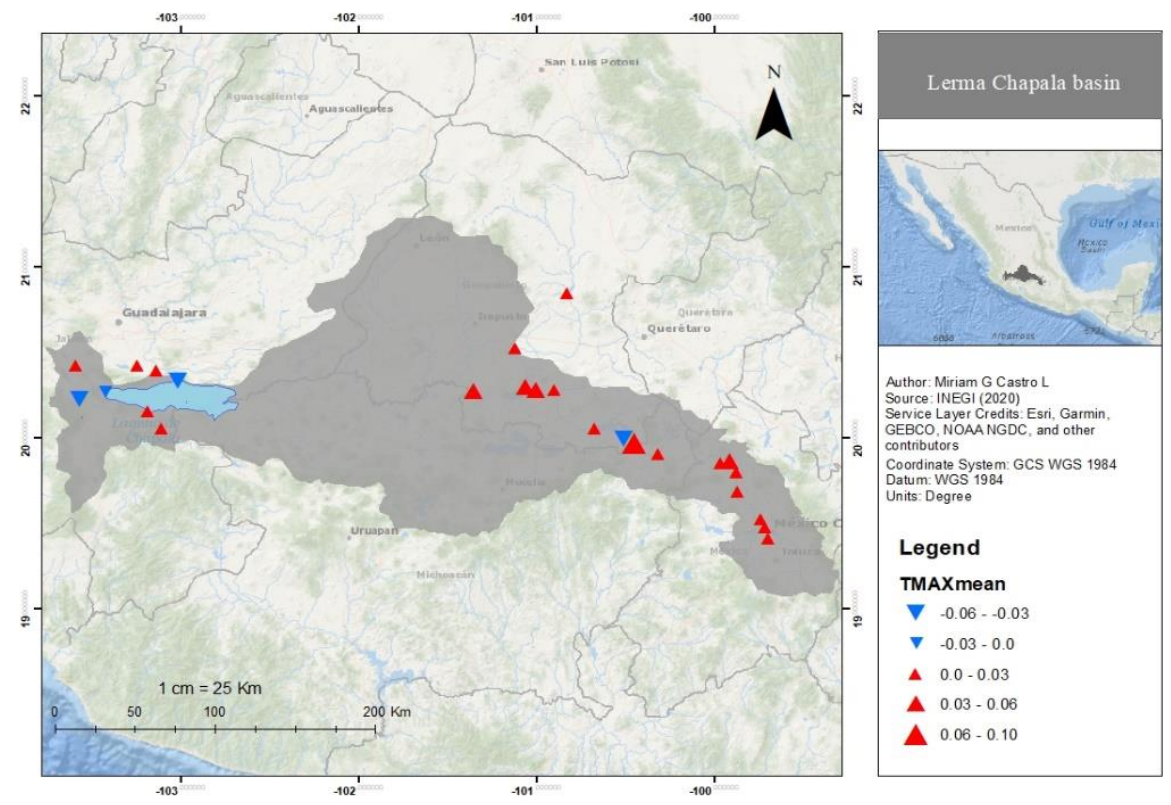

Figure 12. Analysis of the average minimum temperature (TMINmean) of the Lerma Chapala basin.

\subsection{Water surface analysis using Landsat satellite imagery}

\subsubsection{Dry season}

The changes in the water spectrum in the geospatial analysis carried out, and between the different years evaluated were found point differences, which, were found to be directly related to the climatic conditions that are presented in the Lerma Chapala basin, and according to figure 12 the data generated by the watershed spectrum are displayed, sorted in descending order; 1990, 2015, 1985 and 2005; Tough, the lake does not reflect the same behavior, that is, according to the years analyzed in order of importance; 
2010, 1985, 1990 and 2005. It should be noted that there are years in which a recovery is reflected in the lake, but without the same dynamics in the basin, or vice versa.

Despite this, there are periods in which there was a smaller water area in the basin, according to the driest year; 2000, 1995, 1990 and 2005. According to lake records, the worst years were 2000, 1995, 1990 and 2005.

\subsubsection{Wet season}

Figure 13 shows the analysis carried out in the basin, which shows a larger area of water in the years 1990, 2015, 1985 and 2010; Nevertheless, it presents periods with a deficit situation by the reduction of the water spectrum; the year 2000, 1985, 2005 and 2018.

It should be noted that the lake, even if it is dependent on the situation upstream has had different dynamics, in which, it has been favored in the periods; 2010, 1985, 1990 and 2005. But, in the years with less water surface have been 2000, 1995, 2015 and 2018.

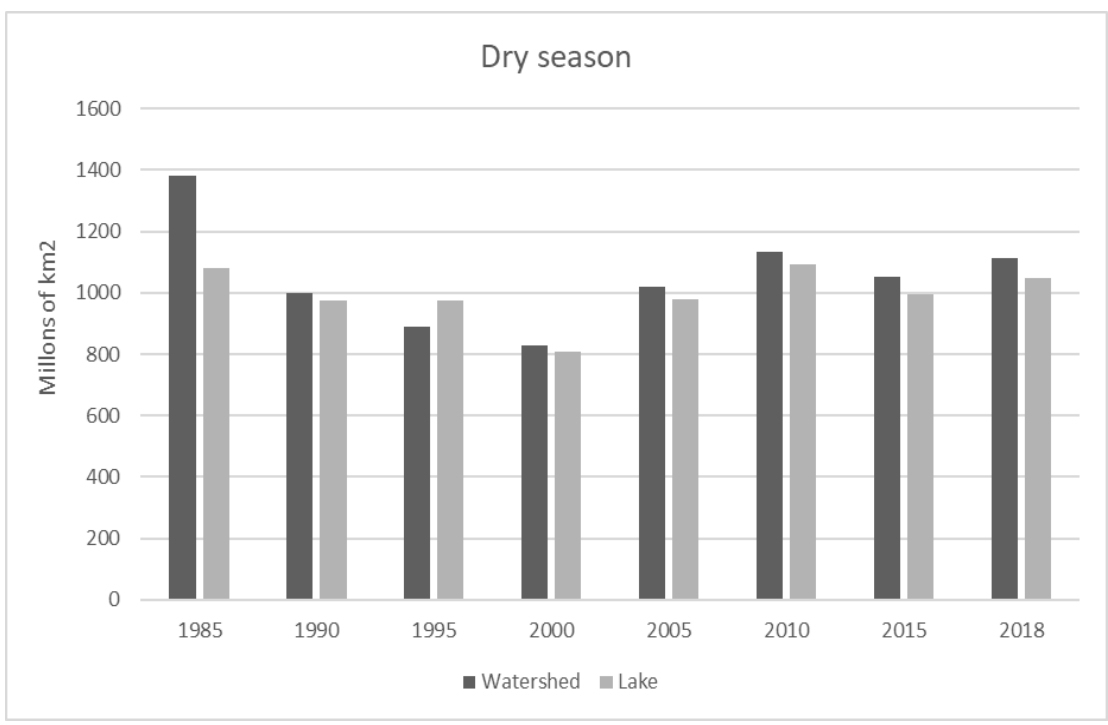

Figure 13. Behavior of the water surface in the Lerma Chapala basin and in Lake Chapala in dry season.

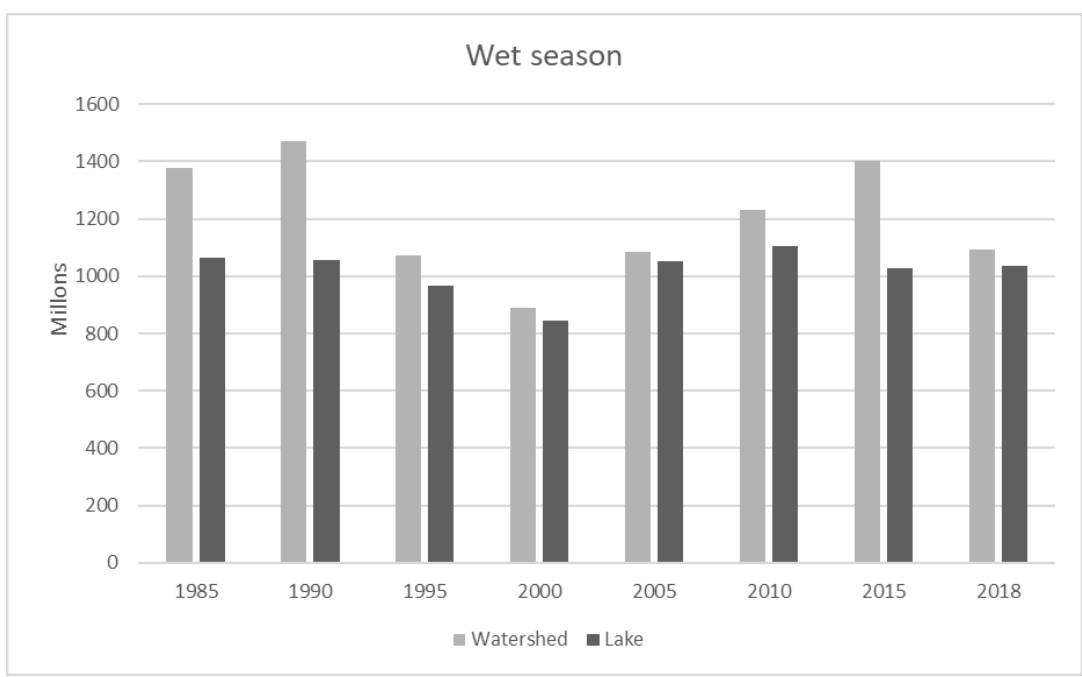

Figure 14. Water surface behavior in the Lerma Chapala basin and Lake Chapala in wet season.

\section{Discussion}


According to the information collected from the dams, it is important to note that the construction of any water works implies that substantially the condition of a basin is substantially modified or altered, although the works are carried out due to the understanding of the cost benefit; the amount of benefits such as: the generation of electricity without greenhouse gas emissions and the reduction of landslides or floods, does not compare to the disadvantages it brings to the region such as the population displacement due to the storage of water from a higher area; the ecological degradation involved, as well as the modification of the hydrodynamic regime of the basin [24]. Similarly, it was found that although dry and semi-dry weather conditions occur in the Lerma Chapala basin, many dams have been built from the upper basin, committing the availability of the resource that reaches Lake Chapala.

Similarly, the analysis through CONAGUA climate databases involved the need to perform homogenization, which is an adjustment technique based on the evaluation of trends where it allows us to focus attention on climatic average, that is, that homogenization results show an improvement of values in databases [25]. The management of RClimdex is used to identify if a region suffers from climate variability; so that once the analysis was conducted, the results were found to show important matches to a study conducted in Ontario, Canada; where it was identified an amplitude in the maximum and minimum temperature range, and which in turn originates regions with drier environments [26]. According to an analysis by Karmalkar et al. (2011) [27] a significant temperature increase is expected in Mexico and Central America, where the bimodal structure disappears and precipitation is dramatically reduced, especially in Mexico, considered as a country highly vulnerable to climatic variability, similarly, according to this project there is a strong relationship with such research, because the behavior of temperature and precipitation variables present modifications that affect the definition of intra-year seasons.

The use of remote sensing and Geographic Information Systems (GIS) derives many positive aspects, such as the identification of perennial and intermittent waterways or bodies, it should be noted that the conditions of greater presence of intermittent flows have a direct relationship with the degree of vulnerability for the purposes of climate change, coupled with the fact that the least developed countries are mainly in the middle latitudes and show a significant change in the rainfall regime [28]. Changes in lake levels are considered to be an important indicator of climate balance and variability; Though, there is some relationship of water levels depending on prevailing weather conditions, i.e. there is a relationship in temperature or precipitation change with the intra annual season [29]. It should be noted that this analysis found a strong relationship of the climatic conditions prevailing in the basin with the surface behavior of Lake Chapala, where a decrease in surface water is observed in the lake, over time, in the basin and in the lake. Fundamentally, the use of satellite images and geostatistical processes, which, allow the analysis of the water surface in a shorter period.

\section{Conclusions}

The determination of variables was given according to the availability of information collected by CONAGUA, in which it was necessary to apply the homogenization tool (Rhtest) due to the amount of suspicious data found. It should be noted that the use of RClimdex was essential to determine whether there is abnormal behavior of climatic variables.

However, it was considered that the analysis of the surface of Lake Chapala involved a broader context, in which it was necessary to present the dams along the basin, where water works built along the Lerma River and intermittent flows were found to undermine the amount of Lerma River flow, and that affects the surface of the body of water.

It is important to mention that, according to the analysis of lake degradation, from 1985 to 2018, it was found that there is a steady decrease in Lake Chapala, that is, i.e. the period from 1995 to 2000 a decrease in water bodies in the basin was seen. Nevertheless, in 2015 there was a recovery in the surface water of the basin, but the same did not happen 
in the lake, so it concluded that although climate variability plays a fundamental role in the problem, the anthropogenic factor is most responsible for the current situation around Lake Chapala, due to the dams that have been built, 517 dams along the Lerma Chapala basin, as well as, up to $60 \%$ water resource extraction of the lake for the supply of water demand by the Metropolitan Area of Guadalajara.

\section{Patents}

Author Contributions: Conceptualization, M.C., A.C. and V.D.; methodology, M.C.; validation, V.D and A.C.; formal analysis, V.D. and A.C.; investigation, M.C.; resources, M.C.; data curation, M.C.; writing-original draft preparation, M.C..; writing - review and editing, V.D. and A.C.; visualization, V.D. and A.C.; supervision, V.D. and A.C.; project administration, A.C.; funding acquisition, M.C.. All authors have read and agreed to the published version of the manuscript.

Funding: This work was funded by National Council of Science and Technology (CONACYT) (Grant No. 862396)

Data Availability Statement: All data necessary to carry out the work in this paper are included in the figures, tables or are available in the cited references.

Acknowledgments: I appreciate the economy support to CONACYT; The orientation and advisor from Valentina Davydova and Abraham Cardenas

Conflicts of Interest: The authors declare no conflict of interest.

\section{References}

1. Urama, K. C., \& Ozor, N. (2014). Impacts of climate change on water resources in Africa. Environmental Engineering and Management Journal, 13(4), 881-889. https://doi.org/10.30638/eemj.2014.092

2. IPCC. (2007). “Cambio climático 2007: Informe de síntesis”. ISBN 92-9169-322-7. En ... de Expertos sobre el Cambio Climático. Ginebra: ....

3. Iglesias, A., Estrela, T., \& Gallart, F. (2005). Impactos sobre los recursos hídricos. 303-354.

4. SEMADET. (2006). Acuerdo de recursos hídricos de la cuenca Lerma Chapala. 62(1), 27-40.

5. Marteau, R., Richard, Y., Pohl, B., Smith, C. C., \& Castel, T. (2014). High-resolution rainfall variability simulated by the WRF RCM: application to eastern France. Climate Dynamics, 44(3-4), 1093-1107. https://doi.org/10.1007/s00382-014-2125-5

6. Wilhite, D. A. (2005). The role of disaster preparedness in national planning with specific reference to droughts. En Natural Disasters and Extreme Events in Agriculture: Impacts and Mitigation. https://doi.org/10.1007/3-540-28307-2_2

7. Zhang, X., \& Feng, Y. (2004). Manual del Usuario. 1-22.

8. Naik, B. C., \& Anuradha, B. (2018). Extraction of Water-body Area from High-resolution Landsat Imagery. International Journal of Electrical and Computer Engineering (IJECE), 8(6), 4111. https://doi.org/10.11591/ijece.v8i6.pp4111-4119

9. Zhiqiang Du, Linghu Bin, Feng Ling, Wenbo Li, Weidong Tian, Hailei Wang, Yuanmiao Gui, Bingyu Sun, X. Z. (2012). Estimating surface water area changes using time-series Landsat data in the Qingjiang River Basin, China. Recuperado de Journal of Applied Remote Sensing website: https://doi.org/10.1117/1.JRS.6.063609

10. Cotler, H., \& Gutiérrez, S. (2005). Inventario y evaluación de las presas en la cuenca Lerma-Chapala. Instituto Nacional de Ecología México, 1-16. Recuperado de http://scholar.google.com/scholar?hl=en\&btnG=Search\&q=intitle:Inventario+y+evaluaci?n+de+presas+de+la+Cuenca+Lerma-+Chapala\#0

11. Cano Sánchez, L. (2003). Ficha Informativa de los Humedales de Ramsar (FIR). Wetlands, 7(1051), 1-12. Recuperado de http://www.citeulike.org/user/LNCScatalogo/article/10575117

12. Durán, J., \& Torres, A. (2003). Introducción En México, del periodo de los cincuenta a la actualidad, el interés ha sido fundamentalmente atender las. 1.

13. Rivas, I., Güitrón, A., \& Montero, M. (2012). Hydrologic vulnerability to climate change of the Lerma-Chapala Basin, Mexico. WIT Transactions on Ecology and the Environment, 167, 297-308. https://doi.org/10.2495/ST110271

14. Boehm, B. (2002). Agua tecnologia y sociedad en la cuenca Lerma Chapala.

15. Comisión Nacional del Agua (CONAGUA). (2011). Lerma - Chapala Basin Case Study Mexico. 1-28. Recuperado de http://www.conagua.gob.mx/CONAGUA07/Contenido/Documentos/LermaChapalaBasinCase.pdf

16. Instituto Nacional de Ecología. (2003). Diagnóstico bio-físico y socioeconómico de la cuenca.

17. Silwal, S. (2010). Assessment of Climate Change Impacts on Water Resources and Vulnerability in Hills of Nepal. Strategies.

18. Comisión Nacional del Agua (CONAGUA). (2011). Lerma - Chapala Basin Case Study Mexico. 1-28. Recuperado de http://www.conagua.gob.mx/CONAGUA07/Contenido/Documentos/LermaChapalaBasinCase.pdf

19. Castro, M. (2019). Influencia de la variabilidad climática en el lago de Chapala, Jalisco.

20. Kansri B., Filippo G., y B. J. (2018). Informe aceptado por el Grupo de Trabajo I del Grupo Intergubernamental de Expertos sobre Cambio Climático, pero no aprobado en detalles. Cuarto Informe de Evaluación, 77. http://www.ipcc.ch/pdf/assessmentreport/ar4/wg1/ar4_wg1_full_report.pdf 
21. IPCC. (2014). Grupo intergubernamental de expertos sobre el cambio climatico. Cambio climático 2014: Informe de síntesis. http://www.ipcc.ch/report/ar5/syr/index.shtml

22. Nacional, S. M. (2018). Información Estadística Climatológica. https://smn.conagua.gob.mx/es/climatologia/informacion-climatologica/informacion-estadistica-climatologica

23. USGS. (2018). Earth Explorer. Recuperado de https://earthexplorer.usgs.gov/

24. Gleick, P. H. (2009). Three Gorges Dam Project, Yangtze River, China. The Worlds Water 2008-2009, 11(1), 139-150 ST-Three Gorges Dam Project, Yangtze Ri.

25. Yan, Z. W., Li, Z., \& Xia, J. J. (2014). Homogenization of climate series: The basis for assessing climate changes. Science China Earth Sciences, 57(12), 2891-2900. https://doi.org/10.1007/s11430-014-4945-x

26. Gaitan, C. F., Hsieh, W. W., \& Cannon, A. J. (2014). Comparison of statistically downscaled precipitation in terms of future climate indices and daily variability for southern Ontario and Quebec, Canada. Climate Dynamics, 43(12), $3201-3217$. https://doi.org/10.1007/s00382-014-2098-4

27. Karmalkar, A. V., Bradley, R. S., \& Diaz, H. F. (2011). Climate change in Central America and Mexico: Regional climate model validation and climate change projections. Climate Dynamics, 37(3), 605-629. https://doi.org/10.1007/s00382-011-1099-9

28. Beharry, S. L., Clarke, R. M., \& Kumarsingh, K. (2015). Variations in extreme temperature and precipitation for a Caribbean island: Trinidad. Theoretical and Applied Climatology, 122(3-4), 783-797. https://doi.org/10.1007/s00704-014-1330-9

29. Jiaming, C., \& Liao, J. (2020). Monitoring lake level changes in China usin multi-altimeter data (2016 - 2019). Jornual of Hydrology, 590. Recuperado de 10.1016/j.jhydrol.2020.125544 